\title{
La imagen de Venezuela y Chávez en la prensa electrónica española
}

\section{The image of Chavez in Venezuela and the Spanish electronic press}

\author{
Dda. Marianela Urdaneta García \\ Universidad Bolivariana de Venezuela \\ haydee2007@hotmail.com
}

Recibido: 10 de Mayo de 2010

Aceptado: 20 de junio de 2010

\section{Resumen}

Se presenta un analizar del tratamiento informativo que los medios españoles -en su versión electrónica-: El Mundo, El País, ABC y la Vanguardia, le dan a la República Bolivariana de Venezuela y al Presidente Hugo Chávez, a fin de conocer cuál es la imagen que construyen sobre ambos. Considerando la estructura y la concentración comunicacional de los medios españoles el presente estudio tiene como objetivo conocer cuál es el tratamiento periodístico que la prensa en España hace sobre la República Bolivariana de Venezuela y su presidente Hugo Rafael Chávez Frías

\section{Summary}

The object of the present work is the way that the mass-media in Spain-by the electronic version-: El Mundo, El País, ABC y La Vanguardia, which it's producing the news refer to the Bolivarian Republic of Venenuela and to his President Hugo Chavez, for to get the image about its that's creating for this media. To take the communicational concentration and structure of the Spain's media into consideration, the present studio take object to know that's the informative action that it's doing about the Bolivarian Republic of Venezuela and his President Hugo Chavez Frias.

Palabras Clave: Información, Medios de comunicación, Presidente, República Bolivariana de Venezuela, España, Colombia

Key Words: Information, Mass-media, President, Bolivarian Republic of Venezuela, Spain, Colombia 


\section{Introducción}

Los medios de comunicación social, como entes garantes del desarrollo de la sociedad tienen un enorme poder para crear en sus receptores comportamientos y creencias a través de las diversas estrategias discursivas que emplean al emitir una información. La transmisión de sus mensajes y símbolos crean en sus receptores una opinión pública positiva o negativa sobre determinado hecho o suceso. Es decir, son una vía esencial para generar en los individuos valores, creencias y códigos de comportamiento que les harán integrarse en las estructuras institucionales de la sociedad.

Desde la Escuela Norteamericana se le atribuye a los "mass media" un rol persuasivo e influyente en los receptores, los cuales de alguna u otra manera, utilizan las informaciones y los hechos presentados por los medios para construir la imagen del mundo que les rodea. Laswell ${ }^{1}$, con su obra "Técnicas de la propaganda en la Guerra Mundial", comenzó en 1927 a proponer su teoría sobre los efectos omnipotentes de los medios y sus consecuencias poderosas sobre el receptor. El modelo de comunicación norteamericano fue el punto de partida para iniciar una de las discusiones más extensas dentro de las ciencias sociales: el efecto del mensaje.

Para estudiar la labor de la prensa en España debemos iniciar diciendo que la actividad comunicativa se encuentra en manos de unos pocos quienes tienen el control, casi absoluto, de la información que circula en el país. Los principales medios de la región están en manos de grandes oligopolios que controlan las diferentes esferas comunicativas como la radio, la televisión, los periódicos, las revistas y las casas editoriales. Entre estos destacan: Grupo Godó, Grupo Prisa, Grupo Vocento, Grupo Zeta, Recoletos, Grupo Moll- Prensa Ibérica, Grupo Joly, Grupo Mediapro, Cadena COPE, Unidad Editorial, los cuales buscan orientar la elección, el contenido y la forma de presentación de los mensajes con los que ciertos acontecimientos son mostrados con miras a manejar y recrear una opinión pública acorde con sus intereses (M' Bow, 1989:22).

Considerando la estructura y la concentración comunicacional de los medios españoles el presente estudio tiene como objetivo conocer cuál es el tratamiento periodístico que la prensa en España hace sobre la República Bolivariana de Venezuela y su presidente Hugo Rafael Chávez Frías.

\footnotetext{
${ }^{1}$ Pionero de las ciencias políticas y de las teorías de la comunicación
} 
Venezuela, país sur-americano, posee una superficie continental e insular de $916.445 \mathrm{~km} 2$. Su principal actividad económica es la explotación y refinación de petróleo para la exportación y consumo interno. Dicho país siempre ha tenido vínculos con España y hoy por hoy, las empresas españolas con mayor presencia e inversión en Venezuela son: BBVA, Repsol YPF, Movistar, Sol Meliá, Iberia, Air Europa, Mapfre, Prisa, Inditex y Elecnor (Oficina Económica y Comercial de España en Caracas, 2009).

Desde 1999 a 2002, las exportaciones españolas hacia Venezuela crecieron en un $19 \%$ y el crecimiento promedio de la importación fue cercano al 30\%. No obstante, para el 2003 y 2004 se produjo una fuerte caída en los intercambios comerciales originados por problemas internos en Venezuela ${ }^{2}$, situación que generó la caída del comercio bilateral a 700 y 890 M\$ respectivamente, manteniéndose el superávit a favor de España. De acuerdo con la Oficina Económica y Comercial de España en Caracas (2009) las exportaciones españolas alcanzaron $575 \mathrm{M} \$$ en el 2005, en 2006 subieron a 654,1 M\$, en 2007 se ubicaron en 798 M\$, volviendo a crecer en 2008 a 939 M\$. Por su parte, las importaciones alcanzaron la cifra de 976 M\$ en 2005, 2.309 M\$ en 2006, 2.062 M\$ en 2007 y 1.943 en 2008. El crudo y el gas acapararon prácticamente el total las compras que España hace a Venezuela, país que vendió petróleo y minerales a España por $1.438 \mathrm{M} \$$ equivalente al $74 \%$ de los productos importados.

Ante la estrecha vinculación existente entre ambas naciones y la importancia que cumplen los medios de comunicación como entes constructores de la imagen y la opinión pública, la presente investigación pretende conocer cuál es la imagen que construyen los principales periódicos de España sobre Venezuela, lo cual permitirá determinar las connotaciones periodística que los diarios en España hacen sobre dicho país de América Latina y su gobernante.

\footnotetext{
${ }^{2}$ En Abril de 2002 la organización patronal Fedecámaras convoca a una huelga general la cual desencadenó un golpe de Estado al Presidente Chávez el día 11. La madrugada del 13 de abril Chávez retoma el poder apoyado por la fuerza popular. Seguidamente, desde diciembre de 2002 hasta febrero de 2003 la oposición venezolana, apoyada por Fedecámaras, la directiva y trabajadores de la empresa Petróleos de Venezuela, los partidos de oposición unificados en la Coordinadora Democrática, el Sindicato de la Confederación de Trabajadores de Venezuela (CTV), la organización Súmate y algunos medios de comunicación privados, ocasionó el sabotaje a la principal industria petrolera del país (PDVSA) la cual generó pérdidas en las reservas del Estado por un monto equivalente e 574 millones de dólares.
} 


\subsection{Objetivo General}

Analizar el tratamiento informativo que los medios: El Mundo, El País, ABC y la Vanguardia, en su versión electrónica, le dan a la República Bolivariana de Venezuela y el Presidente Hugo Chávez, a fin de conocer cuál es la imagen que construyen sobre ambos.

\section{Metodología}

El estudio será efectuado bajo la técnica del Análisis de Contenido, entendido como un método que permite recopilar, procesar y analizar información combinando elementos cuantitativos y cualitativos. El análisis de contenido tiene como objetivo descubrir, los elementos textuales o visuales que contienen determinadas unidades de muestreo, registro y contexto, centrándose en una entidad, idea, persona, discurso o acontecimiento para tratar de averiguar como está representada o conceptualizada es decir, permite conocer cuál es su imagen simbólica, por medio del análisis de los atributos que se le asignan y de las asociaciones o disociaciones que se establecen (Krippendorff, 1990).

\subsection{Muestra}

La muestra está conformada por la versión electrónica de los siguientes periódicos: El Mundo (http://www.elmundo.es/), El País (http: www.elpais.es), ABC (http: www.abc.es) y la Vanguardia (http: www.lavanguardia.es).

En total se analizarán 82 trabajos periodísticos. Distribuidos de la siguiente manera:

\begin{tabular}{|l|r|}
\hline \multicolumn{1}{|c|}{ Periódico } & Número de publicaciones \\
\hline El País & 17 \\
\hline El Mundo & 28 \\
\hline ABC & 20 \\
\hline La Vanguardia & 17 \\
\hline Total & 82 \\
\hline
\end{tabular}

La muestra es analizada desde el 28 de octubre al 15 de noviembre de 2009. 


\section{Análisis}

La presente investigación está estructurada en dos partes. En primera instancia, se hace un análisis de cada periódico, para luego hacer una generalización de los datos.

\subsection{El Mundo}

Tiene su sede en Madrid y cuenta con ediciones Cataluña, País vasco, Andalucía, Almería, Huelva, Valencia, Castilla- La Mancha, Castilla y León, Islas Baleares, Canarias (en colaboración con La Gaceta de Canarias), Alicante, Cantabria, entre otros. Su tirada diaria es equivalente a 408.736 ejemplares.

En el periodo en estudio, El Mundo le dio cobertura a los hechos presentados en Venezuela en 27 oportunidades, la cuales giraron en torno a: conflicto Colombia- Venezuela, vinculación de Venezuela en temas de droga, el racionamiento de agua y luz propuesto por el Presidente de Chávez entre otros.

Veamos en forma detallada cuál fue el tratamiento de los temas abordados:

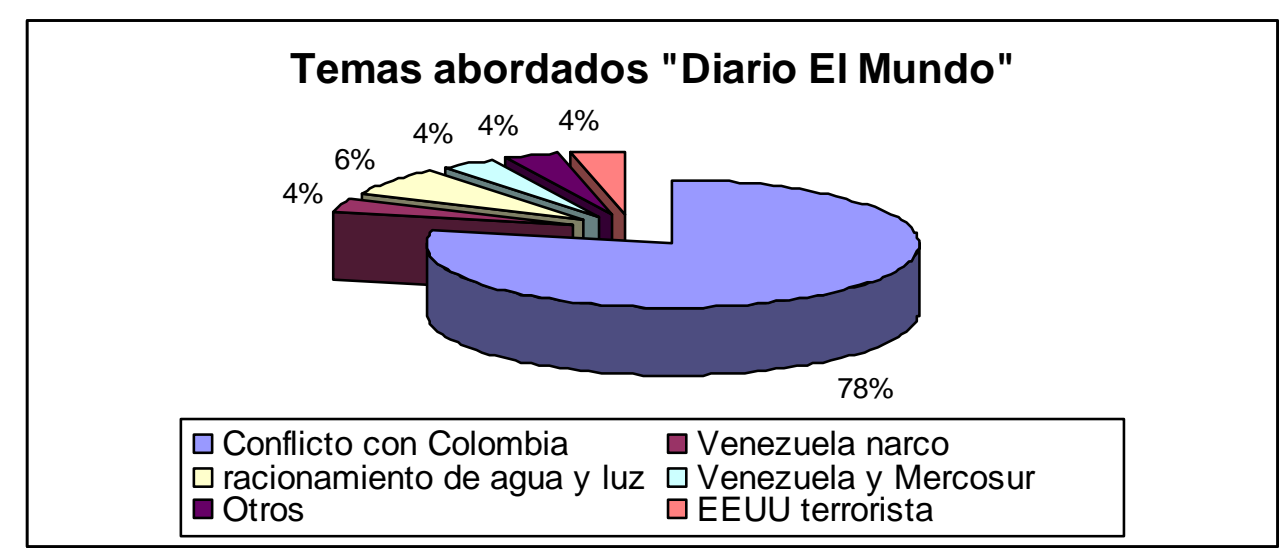

Gráfico No. 1 Temas abordados Diario El Mundo. 


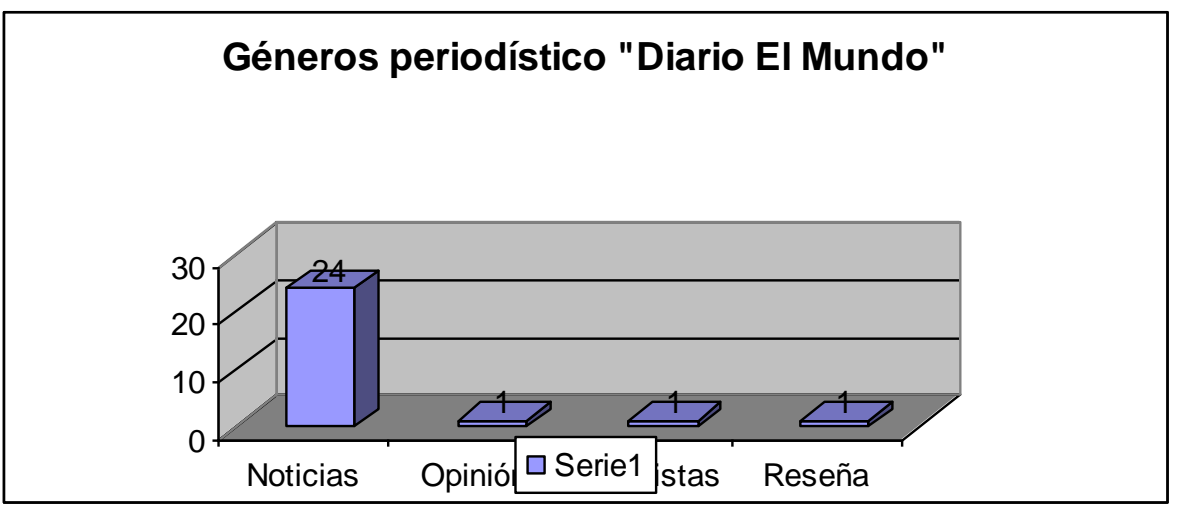

Gráfico No. 2 Géneros periodísticos Diario El Mundo.

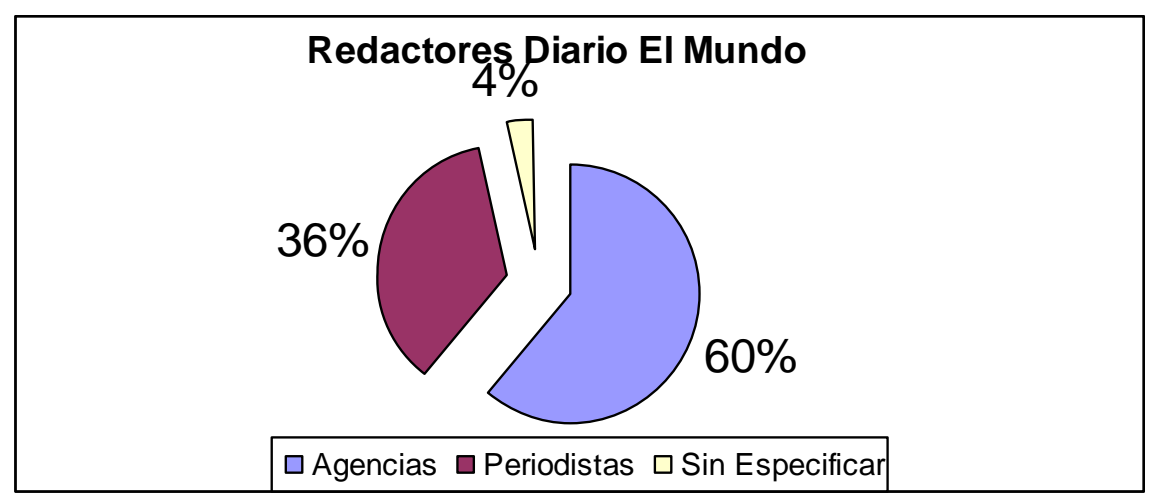

Gráfico No. 3 Redactores Diario El Mundo.

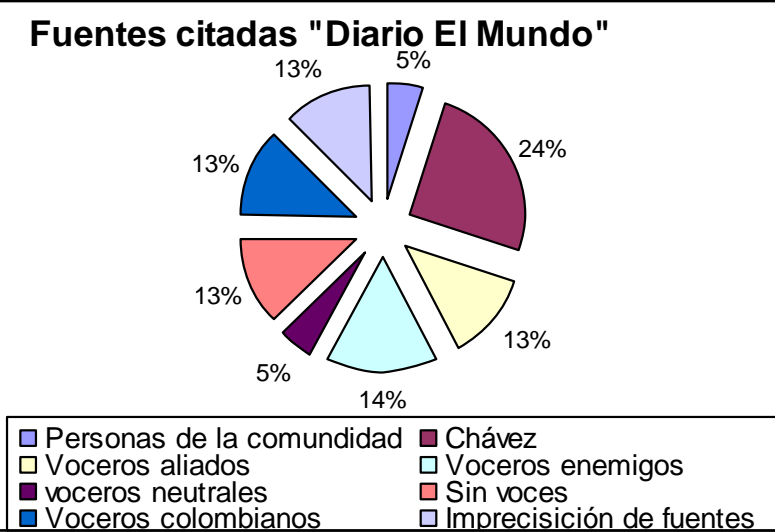

Gráfico No. 4 Fuentes citadas Diario El Mundo. 


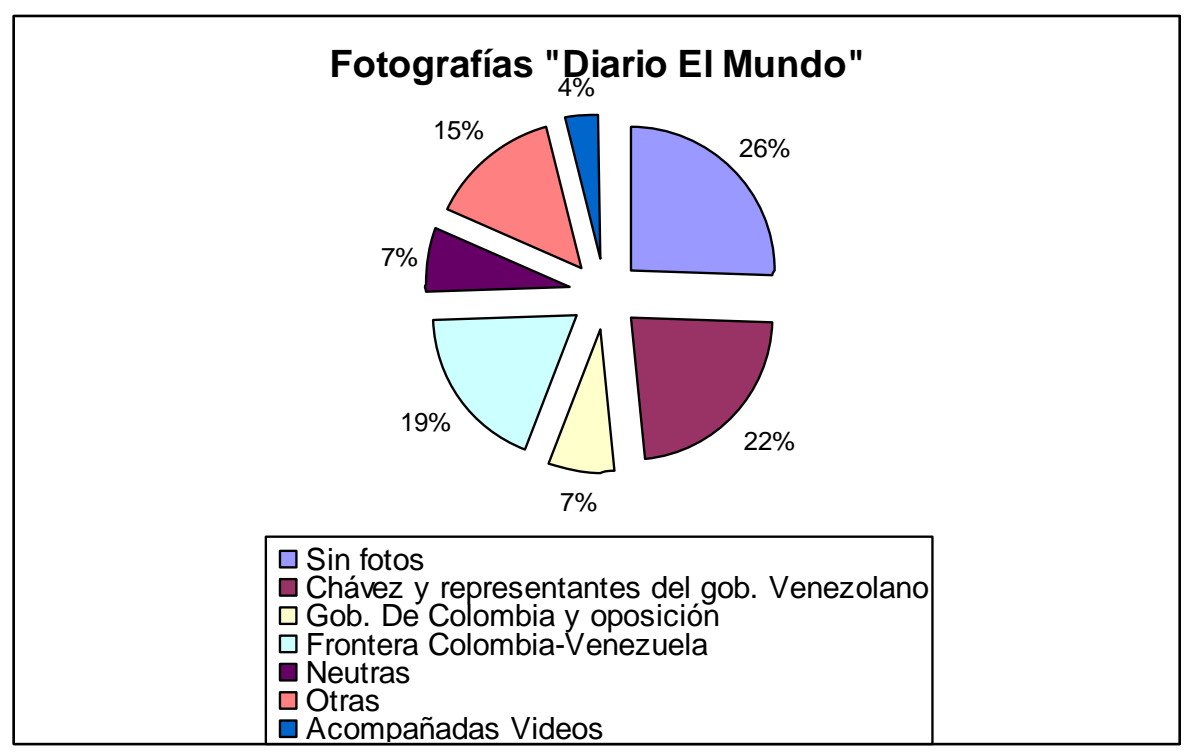

Gráfico No. 5 Fotografías Diario El Mundo.

Una vez conocida estas cifras se procederá a efectuar el análisis y cruzar algunas variables para comprender de la mejor forma las estrategias que emplea dicho diario, en su versión electrónica, para construir la imagen de Venezuela:

1) Al observar el gráfico No. 1 podemos apreciar que el $78 \%$ de su cobertura estuvo centrada en el conflicto Colombia - Venezuela, originado por el acuerdo firmado entre Colombia y los EEUU para instalar siete bases militares en el hermano país con miras a "combatir el narcotráfico".

Se empleó la noticia como género principal para dar a conocer los hechos. Ahora al revisar quiénes son los redactores podemos ver que las mismas proceden en un $60 \%$ de las agencias de noticias como EFE (Agencia Española) Reuters (canadiense-británica) y AFP (Agence France Press). Considerando dicho tratamiento aquí me permito recordar las palabras del exdirector General de la Unesco Amador Mahtar M`Bow cuando expresó que "la libertad de expresión y de información se falsea cuando es controlada por grupos que escamotean el ejercicio de esa libertad a sus pueblos, o cuando los países con menos recursos dependen, informativamente hablando, de las grandes agencias de los países desarrollados"

Los grupos con mayor poder construyen y reconstruyen una realidad acorde con sus intereses, pero para efectos de esta investigación me limitaré a seguir mostrando datos. 
2) Los epígrafes son empleados para introducir "negativamente" el tema a abordar, en ese caso, la imagen de Venezuela y de Chávez:

\begin{tabular}{|c|c|c|}
\hline Epígrafes empleados & Fecha & Comentarios \\
\hline CONFLICTO & $15-11-2009$ & \multirow{16}{*}{$\begin{array}{l}\text { El } 67 \% \text { de las notas que } \\
\text { poseen epígrafes lo } \\
\text { emplean para hacer un } \\
\text { anclaje negativo sobre } \\
\text { Venezuela y la situación del } \\
\text { país. Vemos en ellos, una } \\
\text { Venezuela y un Chávez en } \\
\text { crisis, conflicto, marchas, } \\
\text { tensión, encontronazos, } \\
\text { violencia, con } \\
\text { intervenciones de la policía } \\
\text { y en búsqueda de pruebas. } \\
\text { Dichos epígrafes son } \\
\text { reforzados con los textos } \\
\text { publicados en los } \\
\text { antetítulos y los títulos. }\end{array}$} \\
\hline HOSTILIDADES & 14-11-2009 & \\
\hline MARCHA & 13-11-2009 & \\
\hline CRISIS & $13-11-2009$ & \\
\hline CRISIS COLOMBIA- VENEZUELA & 13-11-2009 & \\
\hline VENEZUELA & $12-11-2009$ & \\
\hline POLICIA & $12-11-2009$ & \\
\hline VENEZUELA & $08-11-2009$ & \\
\hline CONFLICTO & $08-11-2009$ & \\
\hline ENCONTRONAZO & $05-11-2009$ & \\
\hline PRUEBAS & $04-11-2009$ & \\
\hline VIOLENCIA & $01-11-2009$ & \\
\hline VENEZUELA & $30-10-2009$ & \\
\hline VENEZUELA & $29-10-2009$ & \\
\hline VENEZUELA & $28-10-2009$ & \\
\hline TENSION & $28-10-2009$ & \\
\hline
\end{tabular}

3) A nivel de antetítulo se refuerza la intención de mostrar a un Chávez conflictivo y a una Venezuela sumergida en la crisis y con serios problemas en la frontera con Colombia.

\begin{tabular}{|c|c|c|}
\hline Antetítulos empleados & Fecha & Comentarios \\
\hline Niega el diálogo con su homólogo & $15-11-2009$ & \multirow{11}{*}{$\begin{array}{l}\text { Acá vemos a un Chávez conflictivo } \\
\text { que se niega a dialogar para } \\
\text { solucionar la situación presentada } \\
\text { con el hermano país. } \\
\text { Se muestra una Venezuela con una } \\
\text { constante crisis: investigaciones por } \\
\text { droga, conflictos en la frontera, } \\
\text { masacres y escasez de agua y } \\
\text { apagones. } \\
\text { Las acciones son atribuidas a } \\
\text { Chávez y a Venezuela pues es El } \\
\text { Presidente venezolano quien niega } \\
\text { diálogo, es Caracas la que ordena } \\
\text { realizar labores de inteligencia, } \\
\text { entre otros. }\end{array}$} \\
\hline Departamento de Vichada & $14-11-2009$ & \\
\hline Hugo Chávez & $13-11-2009$ & \\
\hline Bases militares & $13-11-2009$ & \\
\hline Conflicto en la frontera & $13-11-2009$ & \\
\hline Apagones & $12-11-2009$ & \\
\hline $\begin{array}{l}230 \text { kilos entre } 17 \text { toneladas de } \\
\text { panelas }\end{array}$ & $12-11-2009$ & \\
\hline 'Aló, Presidente' & $08-11-2009$ & \\
\hline Respuesta a Caracas & $08-11-2009$ & \\
\hline Tensión con Venezuela & 07-11-2009 & \\
\hline Bogotá critica a Caracas & $05-11-2009$ & \\
\hline
\end{tabular}




\begin{tabular}{|c|c|}
\hline Funcionarios del DAS & $04-11-2009$ \\
\hline $\begin{array}{l}\text { Caracas ordena a sus } \\
\text { diplomáticos realizar labores de } \\
\text { inteligencia }\end{array}$ & 04-11-2009 \\
\hline A pesar de las críticas & 03-11-2009 \\
\hline Escasez de agua en Venezuela & 02-11-2009 \\
\hline En la frontera & $01-11-2009$ \\
\hline Tras la masacre de futbolistas & $28-10-2009$ \\
\hline
\end{tabular}

4) En relación a los títulos la situación es muy similar. En un 68\% hacen referencia a Venezuela y a Chávez pero de una manera violenta y conflictiva. Es el Presidente venezolano quien ofende, pide, insiste, hace llamamientos de guerra, acusa, modera entre otros.

Ejemplos:

\begin{tabular}{|c|c|c|}
\hline Títulos empleados & Fecha & Comentarios \\
\hline $\begin{array}{l}\text { Chávez: 'No tengo nada que hablar con el } \\
\text { mafioso de Uribe' }\end{array}$ & $15-11-2009$ & \multirow{10}{*}{$\begin{array}{l}\text { Chávez es el agente que } \\
\text { provoca cambios sobre } \\
\text { el sujeto paciente y } \\
\text { víctima que es Colombia } \\
\text { y su gobernante. } \\
\text { En } 3 \text { de los títulos donde } \\
\text { se hace referencia a } \\
\text { Chávez se emplea el } \\
\text { término amenaza con lo } \\
\text { cual a personalidad del } \\
\text { gobernante venezolano } \\
\text { se torna más agresivo y } \\
\text { conflictivo. }\end{array}$} \\
\hline $\begin{array}{l}\text { Chávez insiste en prepararse frente a la } \\
\text { amenaza de EEUU a través de Colombia }\end{array}$ & 13-11-2009 & \\
\hline $\begin{array}{l}\text { Chávez modera su tono pero no frena las } \\
\text { quejas de Uribe ante la ONU }\end{array}$ & 13-11-2009 & \\
\hline $\begin{array}{l}\text { 'Si Chávez quiere, le enseño dónde están los } \\
\text { campamentos guerrilleros' }\end{array}$ & $12-11-2009$ & \\
\hline $\begin{array}{l}\text { Llamamiento de Carlos Andrés Pérez ante la } \\
\text { amenaza belicista de Hugo Chávez }\end{array}$ & $10-11-2009$ & \\
\hline $\begin{array}{l}\text { Alarma en América por las amenazas de } \\
\text { guerra de Hugo Chávez contra Colombia }\end{array}$ & 10-11-2009 & \\
\hline $\begin{array}{l}\text { Chávez pide a civiles y militares prepararse } \\
\text { para la guerra }\end{array}$ & $08-11-2009$ & \\
\hline $\begin{array}{l}\text { Chávez aplaude al Senado brasileño por } \\
\text { aprobar su entrada al Mercosur }\end{array}$ & 30-10-2009 & \\
\hline El bolígrafo rojo de Hugo Chávez & 29-10-2009 & \\
\hline $\begin{array}{llll}\text { Hugo Chávez: 'EEUU es el primer } \\
\text { patrocinador del terrorismo' } & & & \\
\end{array}$ & $28-10-2009$ & \\
\hline
\end{tabular}

En los títulos vemos que ni el bolígrafo del mandatario venezolano escapó de la perspicacia de los periodistas y en el cuerpo del trabajo le atribuyeron al objeto elementos negativos relacionados con el gobierno de Venezuela. Ejemplo: 
"Con trazos rojos, el líder bolivariano firmó normativas que permiten expropiar firmas agroalimentarias, complejos turísticos y empresas de servicios petroleros. También aprobó legislaciones que restan competencias a los líderes de la oposición que ganaron cargos regionales en los comicios de 2008, y una polémica Ley Electoral, que favorece a los partidos mayoritarios".

Por su parte, Venezuela es mostrada como un país donde imperan los secuestros, la corrupción, las drogas y no hay luz ni agua. Es decir estamos frente a una Venezuela caótica a causa de las "malas políticas de Chávez".

\begin{tabular}{|l|c|}
\hline \multicolumn{1}{|c|}{ Títulos empleados } & Fecha \\
\hline \begin{tabular}{l} 
Los secuestros aumentan un 80\% en la frontera de \\
\hline Colombia y Venezuela
\end{tabular} & $14-11-2009$ \\
\hline $\begin{array}{l}\text { Detenidos cuatro miembros de la Guardia Nacional } \\
\text { venezolana }\end{array}$ & $14-11-2009$ \\
\hline $\begin{array}{l}\text { Venezuela dice que los colombianos masacrados eran } \\
\text { paramilitares }\end{array}$ & $05-11-2009$ \\
\hline Pruebas venezolanas sobre el espionaje colombiano & $04-11-2009$ \\
\hline 'Duchas revolucionarias' de tres minutos escasos & $02-11-2009$ \\
\hline
\end{tabular}

5) Colombia es reflejada como una víctima más de las agresiones del Presidente Venezolano. En los titulares mostrados por El Mundo al agresor del continente (por instalar bases norteamericanas y ceder suelo latinoamericano a las pretensiones de los EEUU) lo trasforman en una víctima y le restan importancia al peligro que significan esas siete bases en nuestra región.

\begin{tabular}{|l|c|}
\hline \multicolumn{1}{|c|}{ Antetítulos empleados } & Fecha \\
\hline $\begin{array}{l}\text { Colombia llevará las 'amenazas de guerra' venezolanas ante } \\
\text { la ONU }\end{array}$ & $14-11-2009$ \\
\hline Bogotá pide la mediación de Madrid & $14-11-2009$ \\
\hline
\end{tabular}

6) En el cuerpo de las noticias hay algunas variables dignas de estudiar. El $22 \%$ de las notas no poseen fotografías (quizás porque provienen de una agencia de noticia), el 19\% son para mostrar las imágenes de la frontera con Colombia (una frontera custodia por la guardia nacional y solitaria). El presidente Chávez es colocado como elemento icónico en un $36 \%$ (22\% en fotografías y $4 \%$ en videos). 
7) A pesar de que en $22 \%$ de las fotos muestran a un Chávez tranquilo, sereno, sonriente, que le da la mano a su pueblo. La estrategia discursiva de los textos muestra a un Chávez violento, agresivo y conflictivo. Si analizamos el gráfico de las fuentes citadas por los periodistas podríamos decir que éstos le dieron una mayor cobertura al Presidente venezolano (24\%). Aunque la realidad es otra, pues si bien es cierto que Chávez tuvo una mayor presencia a la hora de ser citado en las notas, también es notorio que los periodistas, en su mayoría, usaron la técnica de la repetición, (repetir las mismas palabras de Chávez en notas distintas con fecha distintas). Ejemplos:

a) El presidente venezolano insistió ayer en que el país debe preparar su "defensa" frente a la "amenaza" (citada en 3 notas).

b) "Hay que hablar con el amo y por eso le digo al presidente (estadounidense, Barack) Obama: no se vaya a equivocar y vaya a ordenar usted una agresión abierta contra Venezuela utilizando a Colombia", sostuvo Chávez en su programa dominical de radio y televisión "Aló, Presidente" (citada en 3 notas).

c) Chávez volvió a subir el tono en la crisis con Colombia al hablar de "prepararse para la guerra" (Citada en 2 notas).

d) "No perdamos un día en la principal misión: tenemos que prepararnos para la guerra y ayudar al pueblo a prepararse para la guerra, es responsabilidad de todos" [...] "Señor comandante de la guarnición militar, batallones de milicia, vamos a adiestrarnos; estudiantes revolucionarios, trabajadores, mujeres, todos listos para defender esta patria sagrada que se llama Venezuela" (Citada en 2 notas).

e) "Sería alta traición a la patria que, sabiendo que se prepara una guerra contra Venezuela, nos quedemos con los brazos cruzados. Estamos obligados a prepararnos para defender la patria de Bolívar aunque nos cueste la vida. Esta patria nunca más será colonia" (Citada en 2 notas).

f) "Son bases de operaciones de guerra contra Venezuela en primer lugar y así lo denunciamos al mundo. Pero nos acusan a nosotros de promover la guerra. ¡Señores Uribe y Obama vayan a lavarse ese paltó!" (eufemismo por ¡váyanse a la m...!). (Citada en 2 notas.

g) "Las siete bases yanquis forman parte de un plan de guerra, porque desde esas bases el imperio va a controlar toda Suramérica con espionaje electrónico, con tecnología de punta", dijo Chávez (Citada en 2 notas). 
h) "Van a grabar conversaciones de todos nosotros, van a saber la posición geográfica de cualquiera que tenga un teléfono encendido, incluso mandar bombas teledirigidas por la señal del teléfono" Citada en 2 notas).

i) Lo he contado: un minuto para mojarse, otro para enjabonarse y el tercero para enjuagarse. (Citada en 2 notas).

j) "Ahora no es tiempo para jacuzzis, bañaderas, vamos a guardar de agua y electricidad ", dijo la semana pasada antes de presentar un plan para hacer $20 \%$ de ahorro energético. (Citada en 2 notas)

8) Como se precisó anteriormente hubo predominio de las noticias, no obstante, se observaron algunos juicios de valor y opiniones (Propios de los géneros de opinión). Veamos algunas citas que se repitieron de alguna manera similar en otras notas:

a) "Chávez volvió a subir el tono en la crisis con Colombia"

b) "Chávez no se puede mostrar más agresivo".

c) “Añadió el presidente, en uno de sus arranques de emotividad”.

9) En el cuerpo de los trabajos periodísticos el presidente Uribe es mostrado con un discurso menos hostil y pacífico (imagen de víctima). Ejemplo:

a) Colombia no ha hecho ni hará un solo gesto de guerra a la comunidad internacional, menos a países hermanos", señaló la presidencia colombiana en un comunicado. (Citada en 2 notas).

b) "El único interés que nos mueve es la superación del narcoterrorismo que durante tantos años ha maltratado a los colombianos" (Citada en 2 notas).

10) En un $26 \%$ se observó imprecisión de fuentes y carencia de voces en las notas (propio de las notas que provienen de las agencias de noticias). Por ejemplo: "La Armada Nacional retuvo a cuatro funcionarios de la Guardia venezolana que se movilizaban por territorio nacional en una lancha, en cuyo interior fueron encontradas maletas que contenían uniformes camuflados de las Fuerzas Armadas de Venezuela", señaló el DAS. 
En este caso habría que preguntarse quién es el portavoz del DAS, o ¿acaso el DAS tiene personalidad y voz propia?

11) En interior de las noticias la imagen del Presidente venezolano y de Venezuela se asocia con drogas, violencia, guerra, asesinatos, secuestros, insultos. Veamos los siguientes señalamientos que se les hace a Venezuela y a las autoridades venezolanas:

a) Corrupción: "Los paracos trabajan con la complicidad de los cuerpos de seguridad del Estado".

b) Pobreza: "Las invasiones, donde malviven en precarias casas de ladrillo rojo y techo de zinc, numerosos desplazados por el conflicto de su país".

c) Asesinatos: "El segundo punto denuncia la falta de voluntad de las autoridades venezolanas a investigar la masacre de nueve colombianos en el estado de Táchira, en octubre pasado".

d) Agresiones: "El gobierno colombiano está cansado no sólo de las diatribas que le lanza Hugo Chávez sino, también, de sus volteretas de cara a la galería, porque en el terreno comercial, el que más preocupa, nada cambia. Cierra y abre las fronteras a su antojo, no permite liberar dólares para pagar a los empresarios, cortó de plano la importación de muchos productos y mantiene en vilo a los que aún se aventuran a hacer negocios pese a la incertidumbre. Tanto es así, que si la crisis sigue por el mismo camino, el PIB colombiano caerá un 1 por ciento. Sólo en octubre, las exportaciones hacia Venezuela cayeron un 71 por ciento". (Párrafo muy cargado de opinión periodística para ser una noticia).

e) Crisis económica: "El venezolano ya amenazó con reducir a cero el intercambio comercial con uno de sus mejores socios, pero los analistas económicos colombianos opinan que no puede permitirse ese lujo.

12) En ninguna de las noticias, géneros de opinión o reseña se abordó las incidencias y repercusiones que puede tener la instalación de las siete bases militares estadounidenses, no sólo en Colombia, sino en el territorio Latinoamericano.

13) Se construye la imagen pacífica y caritativa de los EEUU. 
"Estamos listos para trabajar de forma conjunta con los países en la región para promover soluciones pacíficas a las disputas en la región", dijo Kelly, al hacer alusión al reciente tira y afloja entre los Gobiernos de Bogotá"

\subsection{El País}

Medio perteneciente al grupo Prisa. Su sede principal está en Madrid. Tiene un promedio o tirada diario equivalente a 524.507 según la Oficina de Justificación de la Difusión (OJD). Cuenta con delegaciones en las principales ciudades de España (Barcelona, Sevilla, Valencia, Bilbao, Santiago de Compostela) desde las que edita diferentes ediciones territoriales. También posee una "edición global" que se imprime y distribuye en América Latina.

Durante el periodo en estudio el diario El País le dio cobertura a Venezuela en 17 oportunidades. Veamos cuál fue su tratamiento:

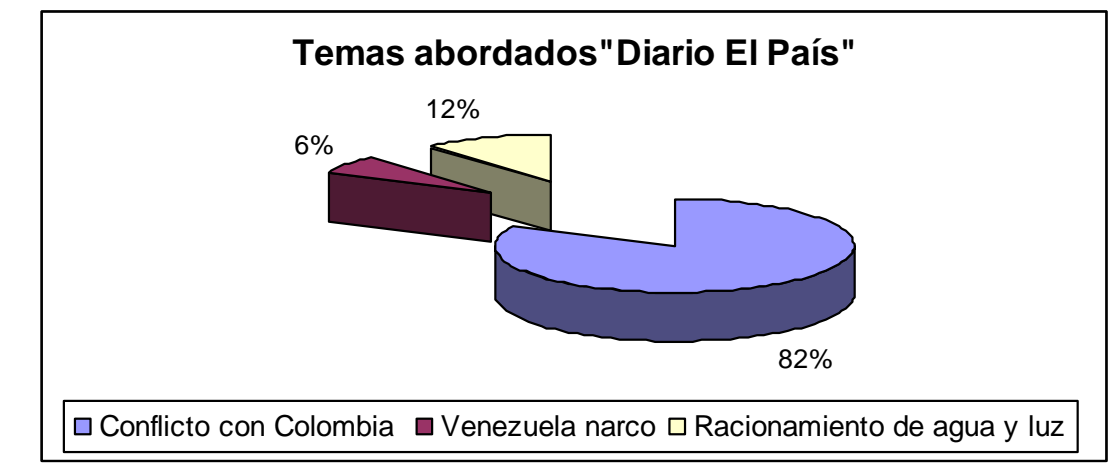

Gráfico No. 6. Temas abordados Diario El País

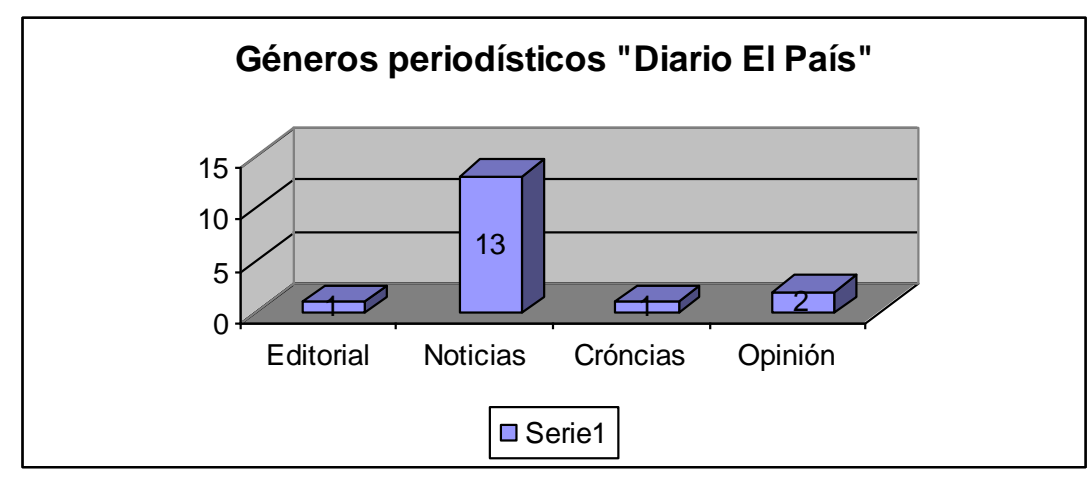

Gráfico No. 7. Géneros periodístico Diario El País

Facultad de Ciencias de la Información - Universidad de La Laguna

Avenida César Manrique, s/n; Campus de Guajara

38071 La Laguna, Tenerife (Islas Canarias - España) 


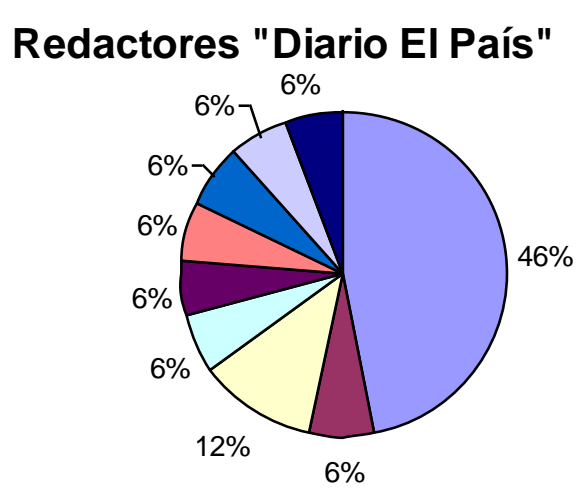

$\begin{array}{lll}\square \text { Maye Primera } & \square \text { Francho Barón| } & \square \text { Pilar Lozano } \\ \square \text { Lydia Garrido } & \square \text { EUROPA PRESS } & \square \text { AGENCIAS (S.E) } \\ \square \text { Opinion del Medio Edit. } & \square \text { Ernesto Samper } & \square \text { M.A. Bastenier }\end{array}$

Gráfico No. 8. Redactores Diario El País

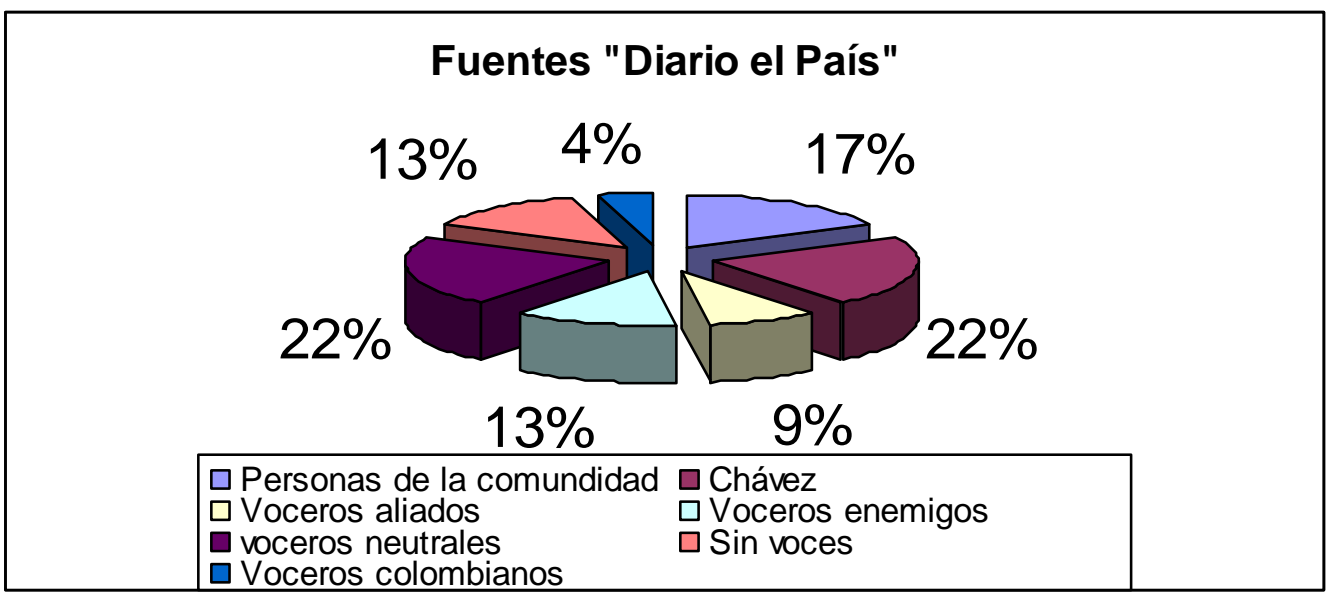

Gráfico No. 9. Fuentes Diario El País

1) El Diario El País también ha dedicado su cobertura periodística (82\%) al conflicto existente entre Colombia y Venezuela, originado por el tema de la instalación de las siete bases norteamericanas en Latinoamérica. En el gráfico No. 6 se puede apreciar que la imagen de Venezuela es asociada con temas que causan una imagen negativa: guerra con Colombia, drogas, carencia de agua y de luz. Los receptores de dichos medios están constantemente bombardeados por estas matrices de opinión y al estar alejados de la realidad que viven los venezolanos toman como única la imagen que difunden en la prensa. 
2) Al analizar los géneros periodísticos más empleados la noticia ocupó un $76 \%$ de toda la muestra, seguida por los artículos de opinión en un 12\%. Sin embargo, en las noticias se evidencian el toque de juicios de valor y opiniones emitidas por sus redactores. Ejemplos:

a) "El miércoles por la tarde, horas después de que Chávez retirara su mensaje incendiario"

b) "La electricidad es una lotería"

c) "Caótica y preocupante. Así es la situación en la frontera entre Colombia y Venezuela"

3) Sólo en una oportunidad se hace mención al peligro que encierra para el pueblo latinoamericano la instalación de las siete bases en Colombia. El artículo de opinión escrito por el ex presidente colombiano, Ernesto Samper Lozano permite dilucidar cuál es la situación de los pueblos vecinos de Colombia una vez instalada las bases estadounidenses.

\section{"Bases militares estadounidenses en Colombia"}

ERNESTO SAMPER PIZANO 12/11/2009

El acuerdo firmado el pasado 30 de octubre entre los Gobiernos de Colombia y Estados Unidos, para permitir la presencia de tropas y el estacionamiento de aeronaves de guerra norteamericanas en siete bases estratégicas colombianas, tendrá unas graves implicaciones en la determinación de la futura política exterior colombiana apenas comparables a las que resultaron cuando, a comienzos del siglo XIX, el país perdió el istmo de Panamá.

\section{Obama ha mandado una señal equivocada ahora que quería cambiar su relación con}

\section{Latinoamérica}

En los documentos internos del Pentágono de enero de este año, antes de existir cualquier negociación con Colombia, ya aparecían señaladas las bases como parte de la estrategia de "aseguramiento estratégico" de los Estados Unidos en el hemisferio suramericano.

Pasado el 11 de septiembre, los Estados Unidos resolvieron comenzar a levantar sus 800 bases en el mundo y construir un nuevo tipo de ellas, las denominadas "bases expedicionarias", que les permitieran vigilar, desde corredores geográficos determinados, a través de distintos sitios de abastecimiento, distintas aéreas del mundo.

Los nuevos enclaves militares norteamericanos en Colombia y, más concretamente, la base de Palanquero, localizada en el corazón del país y considerada la fortaleza emblemática de nuestra Fuerza Aérea, cumplirá este objetivo de aseguramiento estratégico de Suramérica y la costa occidental de África a través de la isla de Ascensión, cercana a la ciudad de Recife en Brasil. 
Aunque los cancilleres de los países firmantes del acuerdo han insistido en que las bases solamente reforzarán la lucha de Colombia contra el narcotráfico y el terrorismo, está claro que por el tipo de equipos que vendrán a ellas como aviones $C-17$, que cargan hasta 70 toneladas de material bélico, aviones Orion dedicados al espionaje electrónico, los poderosos aviones Awad, verdaderas plataformas volantes de inteligencia y los Boeing 707, los nuevos equipos no serán para transporte masivo de narcotraficantes, fumigación aérea de cultivos ilícitos o localización de terroristas en las selvas amazónicas[...]

Lo único más grave que los acuerdos ha sido la forma como se ha manejado la información sobre ellos, de manera casi clandestina, a escondidas de la opinión pública y sin la participación de los Congresos de los dos países. El de Colombia, inclusive, desconoció la recomendación que le hizo el Consejo de Estado -organismo asesor, según la Constitución, del poder Ejecutivo-, que le aconsejó, dada la trascendencia del tema, llevarlo a la discusión del Congreso de Colombia y someterlo después al análisis de la Corte Constitucional".

No obstante, el tema de los efectos de las bases en Latinoamérica ha sido obviado por la prensa española, la cual se ha centrado en colocar a los agredidos como agresores. ¿Quién les garantiza a los pueblos de Venezuela, Ecuador, Bolivia, Nicaragua, Brasil, Argentina entre otros; que esas bases no serán usadas el día de mañana para tener control y dominio sobre Latinoamérica?

4) A nivel de la autoría y redacción de los trabajos periodísticos se precisó que en un $70 \%$ éstos fueron elaborados por periodistas. Se le atribuye a Maye Primera la elaboración del $48 \%$ de los mismos.

El $12 \%$ proceden de agencias de noticias, otro 12\% lo integran artículos de opinión (uno a favor de la instalación y otro en contra) y un 6\% ocupa el editorial del medio, del cual sólo al leer "Chávez se pasa" se conoce la tendencia y orientación. Dicho editorial tampoco contempla en ninguna de sus líneas las repercusiones de las bases para los países vecinos y deja a entrever que Ecuador, Argentina Brasil, Bolivia y Nicaragua tienen una paranoia con el tema de la instalación de las bases, las cuales serán usadas sólo "para combatir el narcotráfico"

Considerando que los editoriales a nivel periodístico son la opinión fidedigna del medio que lo emite y que a su vez aportan herramientas para conocer la agenda que aplicará el medio en determinado caso, podemos ver la tendencia que muestra el diario la cual se refleja como:

a) En contra de Chávez: Las opiniones eran negativa no sólo al momento de referirse a Chávez sino al hablar de la postura de los países latinoamericanos. Veamos algunos extractos del editorial: 
"el inventor del chavismo, presunta izquierda radical latinoamericana, se ha pasado de la raya"

"El líder bolivariano, raudo en distinguir una oportunidad propagandística”

"con grados diversos de intensidad, la medida tampoco gustaba en Brasil ni Argentina, no digamos ya en países de chavismo nominal como Ecuador, Bolivia y Nicaragua”.

"Alertado, quizá, de que sus estentóreas acusaciones no estaban cayendo bien en casi ninguna parte, Chávez..."

"Y le estaba sacando provecho ante una opinión mayoritaria en América Latina a la que incomoda la idea de la presencia de tropas extranjeras en su suelo"

“La oposición en Caracas afirma que el líder bolivariano ha sufrido un ataque de pánico porque las encuestas denotan un descenso del apoyo popular cuando el desabastecimiento de productos de primera necesidad, los cortes de fluido eléctrico y la inseguridad ciudadana son ya una endemia más extensa que la gripe $A$ "

"La paradoja es que con tal algarabía de sinsentidos, Chávez está, si no justificando, sí aportando razones en retrospectiva para que Colombia busque apoyo militar externo. No para agredir; para defenderse.

b) A favor de las bases militares y de Colombia: Se abordan el tema únicamente desde la perspectiva de cooperación para combatir narcotráfico.

"Bogotá cede el uso de siete bases militares a Washington para combatir el narcotráfico"

"Pero de eso a prestar a Colombia propósitos agresivos, además de afirmar que Bogotá no hace sino poner en práctica los mandatos de Estados Unidos, media un grotesco abismo"

"Pues que se tranquilice: Colombia, aunque se lo pidiera de rodillas Washington, ni por todo el oro del mundo iba a atacar".

"Uribe está plenamente legitimado, como anuncia, para elevar el problema a la OEA y al Consejo de Seguridad"

5) Los titulares muestran la agenda del medio a la hora de construir la imagen de Venezuela y el Presidente Chávez. Chávez es presentado como agente de cambio en el otro. Es decir, es Chávez quien rechaza, se pasa, se hunde, dice, tiene guerras, críticas, ordena, amenaza de guerra y pone coto. A continuación se muestran las evidencias: 


\begin{tabular}{|c|c|c|}
\hline Títulos empleados & Fecha & Comentarios \\
\hline $\begin{array}{llll}\text { El presidente venezolano rechaza la } \\
\text { propuesta de Brasilia }\end{array}$ & 14-11-2009 & \multirow{8}{*}{$\begin{array}{l}\text { El } 47 \% \text { de los títulos } \\
\text { elaborados se refieren a } \\
\text { un Chávez que ejecuta } \\
\text { acciones negativas: } \\
\text { declara, se pasa, se } \\
\text { hunde, ordena, hace } \\
\text { guerras, pone coto, entre } \\
\text { venezolano se torna más } \\
\text { agresivo y conflictivo. }\end{array}$} \\
\hline Chávez se pasa & 12-11-2009 & \\
\hline $\begin{array}{l}\text { Los cortes de agua y luz hunden a Hugo } \\
\text { Chávez en los sondeos }\end{array}$ & $12-11-2009$ & \\
\hline $\begin{array}{l}\text { Chávez dice que no ha declarado la guerra a } \\
\text { Colombia }\end{array}$ & $11-11-2009$ & \\
\hline La guerra de Hugo & $11-11-2009$ & \\
\hline $\begin{array}{l}\text { Críticas a Chávez por llamar a las armas } \\
\text { contra Colombia }\end{array}$ & $11-11-2009$ & \\
\hline $\begin{array}{l}\text { Chávez ordena al Ejército que se prepare } \\
\text { para la guerra con Colombia }\end{array}$ & 09-11-2009 & \\
\hline $\begin{array}{l}\text { Chávez "pone coto" al capitalismo con cortes } \\
\text { de agua y de electricidad }\end{array}$ & $31-10-2009$ & \\
\hline
\end{tabular}

Colombia desempeña el papel de víctima, es quien se queja, denuncia y debe padecer las consecuencias que implica romper las relaciones diplomáticas con su país vecino.

\begin{tabular}{|l|c|}
\hline \multicolumn{1}{|c|}{ Títulos empleados } & Fecha \\
\hline Los 'pimpineros' de la frontera & $15-11-2009$ \\
\hline $\begin{array}{l}\text { Bogotá presenta sus quejas ante la ONU pese a la } \\
\text { rectificación de Chávez }\end{array}$ & $13-11-2009$ \\
\hline $\begin{array}{l}\text { Colombia denunciará en la ONU las "amenazas de guerra" } \\
\text { de Chávez }\end{array}$ & $09-11-2009$ \\
\hline Desconcierto fronterizo en Cúcuta & $05-11-2009$ \\
\hline $\begin{array}{l}\text { Los pasos fronterizos entre Colombia y Venezuela, de } \\
\text { nuevo cerrados }\end{array}$ & $04-11-2009$ \\
\hline
\end{tabular}

6) A nivel de las fuentes citadas en el cuerpo de las noticias vemos que en 5 de las 17 notas se cita directamente al Presidente venezolano (22\%) y es para mostrar sus agresiones contra Colombia y los EEUU. Ejemplos:

a) "Son las bases militares yanquis" (citada en 2 notas)

b) "El gobierno de Colombia no está en Bogotá, ahora está en Estados Unidos" (citada en 2 notas)

c) "Compañeros militares, no perdamos un día en el cumplimiento de nuestra principal misión: prepararnos para la guerra y ayudar al pueblo a prepararse para la guerra, porque es 
una responsabilidad de todos. (...) No pierdan tiempo, vamos a formar los cuerpos de milicias, los estudiantes, los trabajadores, las mujeres, todos listos para defender esta patria sagrada que se llama Venezuela, patria santa", ha añadido, extendiendo también el llamamiento a comandantes de batallones y milicias, a estudiantes revolucionarios, trabajadores y mujeres. "Todos listos para defender esta patria sagrada" (citada en 2 notas)

e) "Tres minutos son suficientes...jy no quedo hediondo!", ha dicho de sus propios baños. O llama al ahorro de electricidad, y amenaza con expropiar los centros comerciales que no reduzcan su consumo de energía, una energía que pertenece al "pueblo".

7) A nivel del código icónico se obtuvo que el $49 \%$ las notas no presentaron fotografías. Otro $34 \%$ estuvo centrado en mostrar aspectos negativos de la crisis colombo-venezolana. De ese $34 \%$, el 17\% contenía el video donde Chávez hace el llamado a las Fuerzas Armadas venezolanas para prepararse a la guerra (usado en 3 notas, distintas y con fechas distintas) el otro $17 \%$ mostraba imágenes de los hechos suscitados en la frontera.

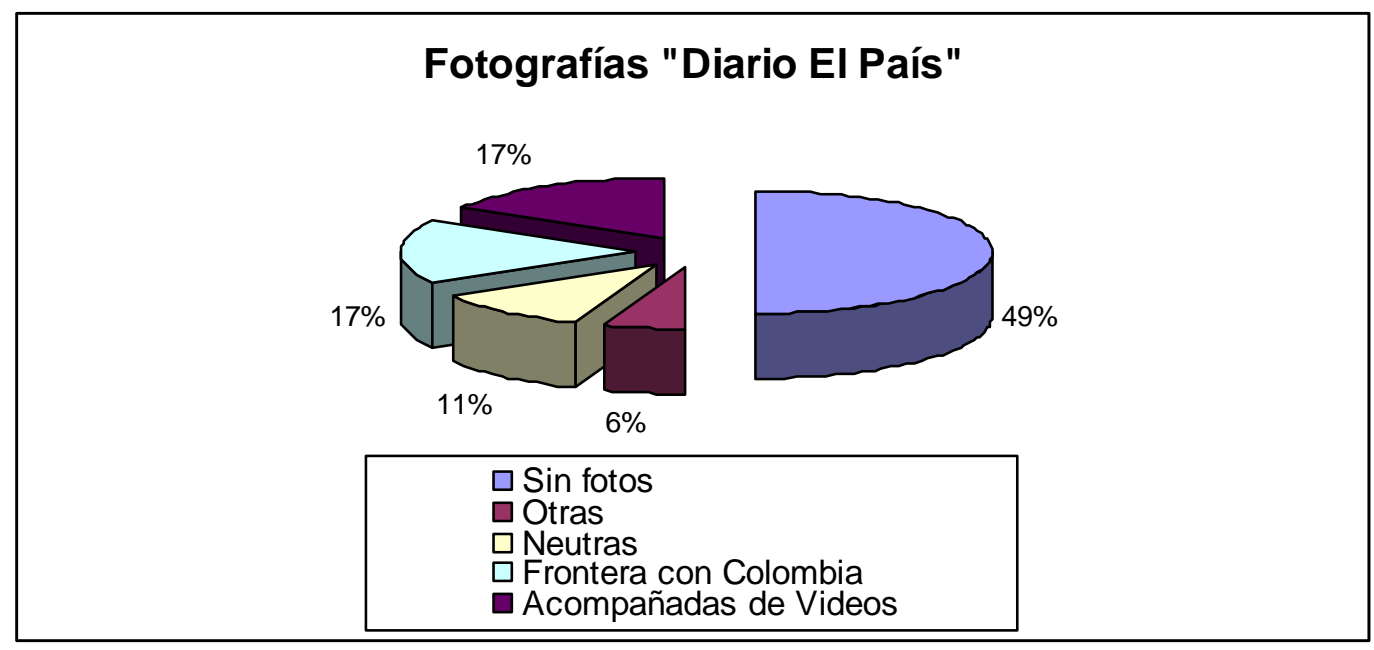

Gráfico No. 10. Fotografías Diario El País

\subsection{La Vanguardia}

Pertenece al grupo Godó. Sede principal en Barcelona. Con una tirada en promedio de 235.361 ejemplares según la OJD. Distribuido en toda España.

La Vanguardia informó sobre los acontecimientos de Venezuela en 17 oportunidades, siendo su tratamiento de la siguiente manera: 


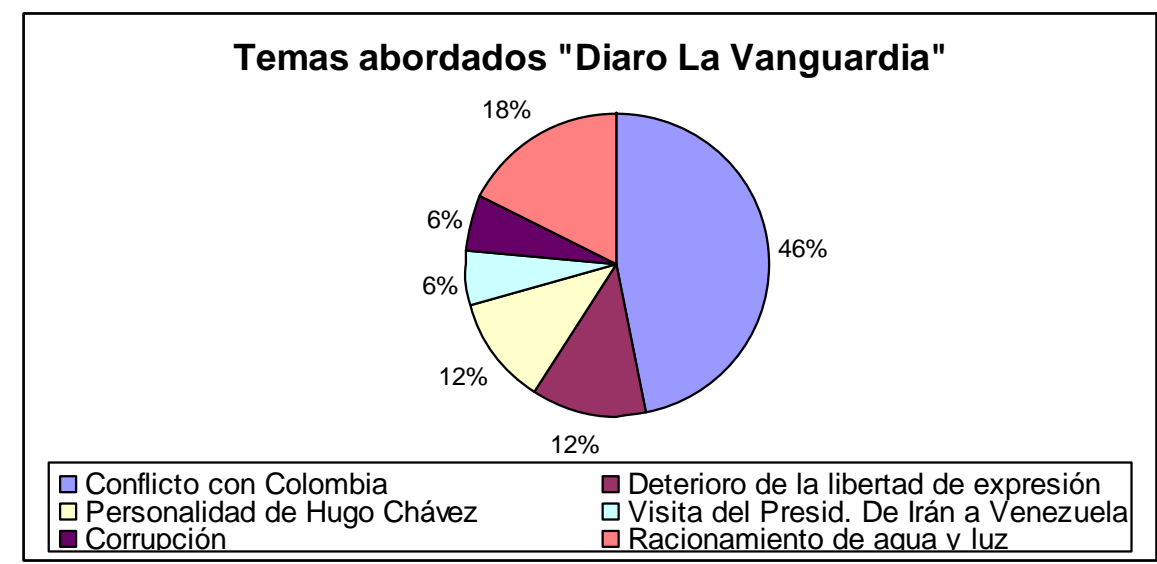

Gráfico No. 11. Temas abordados Diario La Vanguardia

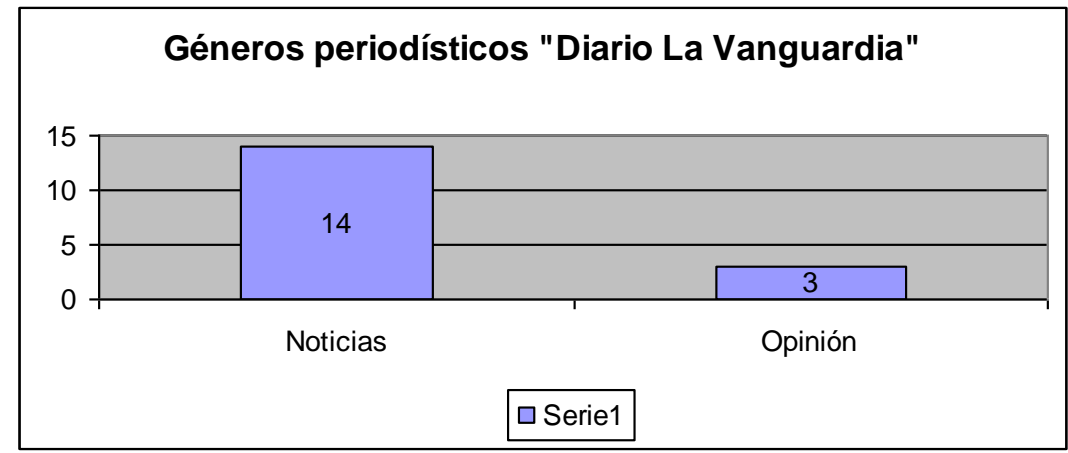

Gráfico No. 12. Géneros periodísticos Diario La Vanguardia

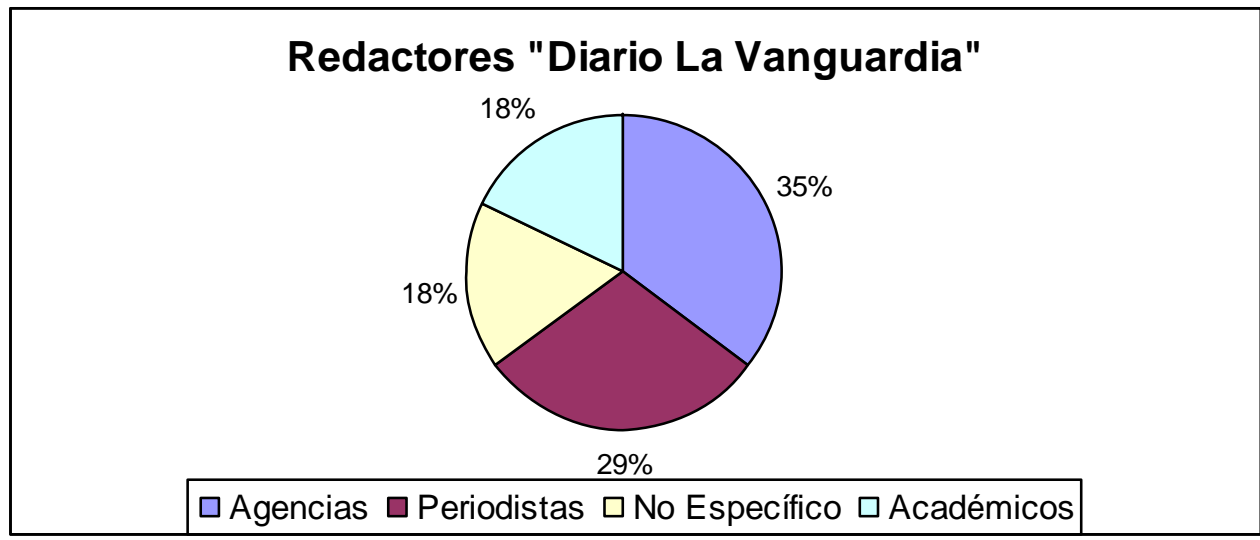

Gráfico No. 13. Redactores Diario La Vanguardia

Facultad de Ciencias de la Información - Universidad de La Laguna

Avenida César Manrique, s/n; Campus de Guajara

38071 La Laguna, Tenerife (Islas Canarias - España) 


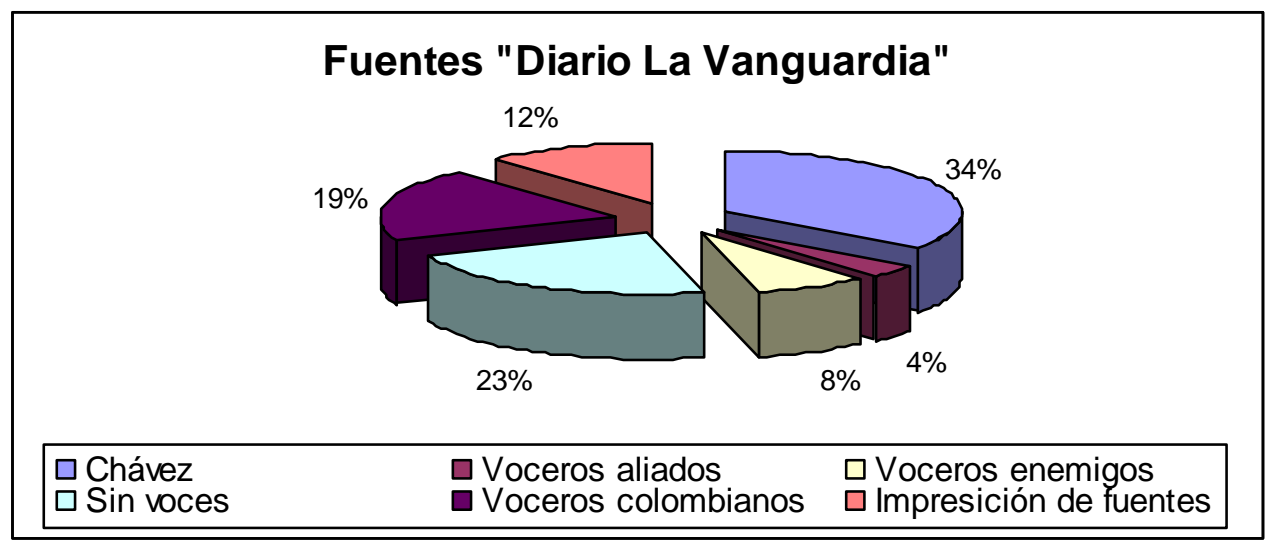

Gráfico No. 14. Fuente Diario La Vanguardia

Fotografías "Diario La vanguardia"

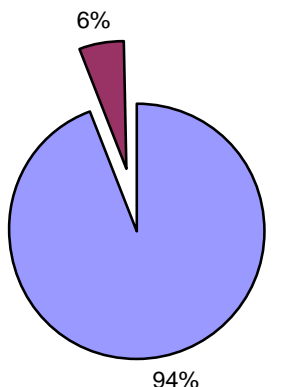

$\square$ Sin fotos $\square$ En contra de Chávez

Gráfico No. 15. Fotografías Diario La Vanguardia

1) Este diario mostró un tratamiento periodístico más variado que los dos medios anteriores. No obstante, todos fueron orientados a fortalecer la imagen negativa sobre Venezuela.

En un $46 \%$ se abordó el tema relacionado con Colombia y Venezuela, seguido del racionamiento de agua y luz llevado a cabo en dicho país (18\%). El resto fue para referirse a la corrupción existente en Venezuela, la personalidad de Hugo Chávez y al deterioro de la libertad de expresión.

2) Hubo predominio del uso de la noticia como género periodístico. Las mismas procedían de las agencias internacionales en un 35\%. Se publicó la opinión de académicos (18\%) para 
analizar a Chávez y a la situación venezolana (desde una matriz negativa). Es fundamental indicar que en un $18 \%$ no se reflejó la procedencia o autoria de los trabajos periodísticos publicados.

3) Al revisar los titulares nos encontramos nuevamente que es Chávez el sujeto que provoca o tiende a provocar un cambio ante "sus víctimas". Es Chávez quien pide, amenaza, marca agendas, se reúne y propone.

\begin{tabular}{|c|c|c|}
\hline Títulos empleados & Fecha & Comentarios \\
\hline $\begin{array}{l}\text { Chávez pide a Obama que renuncie al premio } \\
\text { Nobel de la Paz }\end{array}$ & $15-11-2009$ & \multirow{8}{*}{$\begin{array}{lr}\text { El } 47 \% \text { de los títulos } \\
\text { elaborados se refieren a } \\
\text { un Chávez en acciones } \\
\text { negativas: ride, } \\
\text { amenaza, rarca } \\
\text { agendas, propone } \\
\text { duchas de } 3 \text { minutos etc. }\end{array}$} \\
\hline $\begin{array}{l}\text { Llamamiento de Carlos Andrés Pérez ante la } \\
\text { amenaza belicista de Hugo Chávez }\end{array}$ & $10-11-2009$ & \\
\hline $\begin{array}{l}\text { Alarma en América por las amenazas de } \\
\text { guerra de Hugo Chávez contra Colombia }\end{array}$ & 09-11-2009 & \\
\hline $\begin{array}{l}\text { Chávez pide a civiles y militares venezolanos } \\
\text { prepararse para la guerra }\end{array}$ & $08-11-2009$ & \\
\hline Chávez marca la agenda & $09-11-2009$ & \\
\hline $\begin{array}{llll}\text { Chávez y Ahmadineyad se } & \text { reunirán } \\
\text { Caracas "antes de fin de año" } & & \\
\end{array}$ & $08-11-2009$ & \\
\hline La ducha chavista & $09-11-2009$ & \\
\hline $\begin{array}{l}\text { Chávez propone una ducha de tres minutos } \\
\text { para ahorrar agua }\end{array}$ & $30-10-2009$ & \\
\hline
\end{tabular}

4) Venezuela es asociada a un país en crisis donde hay corrupción, racionamiento de agua y de luz y la prensa es acosada por estar en contra del gobierno.

\begin{tabular}{|l|c|l|}
\hline \multicolumn{1}{|c|}{ Títulos empleados } & Fecha & \multicolumn{1}{c|}{ Comentarios } \\
\hline $\begin{array}{l}\text { Venezuela, Ecuador y } \\
\text { Argentina }\end{array}$ & $12-11-2009$ & $\begin{array}{l}\text { Se plantea que en Venezuela los periodistas } \\
\text { están en una constante amenaza ante el gobierno } \\
\text { que coarta la libertad de expresión y cierra } \\
\text { emisoras. Ejemplo: "No es casualidad que varios }\end{array}$ \\
\hline
\end{tabular}




\begin{tabular}{|l|l|l|}
\hline $\begin{array}{l}\text { Acoso a la prensa en } \\
\text { América Latina }\end{array}$ & $11-11-2009$ & $\begin{array}{l}\text { gobiernos estén unidos por una ideología } \\
\text { exportada por Chávez, quien ha cerrado 34 } \\
\text { emisoras de radio y dos canales". }\end{array}$ \\
\hline $\begin{array}{l}\text { Los estados de la } \\
\text { corrupción }\end{array}$ & $08-11-2009$ & $\begin{array}{l}\text { En el texto se indica que Venezuela es el país } \\
\text { "número 54 en renta, ocupa el lugar 158 en } \\
\text { corrupción". }\end{array}$ \\
\hline "Yo no quedo hediondo" & $30-11-2009$ & $\begin{array}{l}\text { Usado para hablar sobre el racionamiento de } \\
\text { agua que se está implementando en Venezuela a } \\
\text { causa de las consecuencias del fenómeno del } \\
\text { Niño. }\end{array}$ \\
\hline
\end{tabular}

5) Cuando se refieren a las acciones de su homólogo colombiano las vinculan completamente con Colombia, es decir no es Uribe quien ejecuta las acciones sino Colombia. Ejemplos:

\begin{tabular}{|l|c|}
\hline \multicolumn{1}{|c|}{ Títulos empleados } & Fecha \\
\hline $\begin{array}{l}\text { Colombia pide a la ONU que estudie las amenazas de guerra } \\
\text { de Venezuela }\end{array}$ & $12-11-2009$ \\
\hline $\begin{array}{l}\text { Colombia anuncia que Ilevará las "amenazas de guerra" de } \\
\text { Hugo Chávez ante la ONU y la OEA }\end{array}$ & $09-11-2009$ \\
\hline
\end{tabular}

6) Observamos que en un $34 \%$ de las notas se cita al mandatario venezolano, pero empleando la estrategia de la repetición. Es decir, se usas las mismas declaraciones en notas y fechas distintas. Ejemplos:

a) "No se vaya a equivocar y vaya a ordenar usted una agresión abierta contra Venezuela utilizando a Colombia" (citada en 3 notas).

"b) "Prepararse para la guerra" (Citada en 2 notas).

c) "El Gobierno de Colombia "se transfirió a Estados Unidos. Esto hay que saberlo, lamentablemente esto es así, es triste y doloroso, pero es así" (citado en 2 notas).

d) "Yo lo he contado: tres minutos es más que suficiente; no quedo hediondo. Un minuto para mojarse, otro para enjabonarse y el tercero para enjuagarse; lo demás es un desperdicio" (citado en 2 notas) 
7) En un $19 \%$ se hace uso de la vocería colombiana para construir la imagen de una Colombia "víctima" de los ataques del presidente venezolano. Es decir, Colombia no tiene otro objetivo que usar las bases con la finalidad de desarrollar acciones contra el narcotráfico y el terrorismo. Ejemplo:

a) "El único interés que nos mueve es la superación del narcoterrorismo que durante tantos años ha maltratado a los colombianos"

b) "Colombia no ha hecho ni hará un solo gesto de guerra a la comunidad internacional, menos a países hermanos".

8) El $34 \%$ de los trabajos elaborados presentan imprecisión y carencia de voces. ¿Un periodismo sin fuente?

9) A nivel del discurso icónico encontramos que las publicaciones carecían de soporte fotográfico en un $94 \%$. Sólo en una oportunidad se recurrió a la fotografía cuya imagen refuerza negativamente al presidente venezolano.

10) En el $100 \%$ de las notas no se hace mención a las repercusiones e incidencias que puede tener para la soberanía de Colombia y de los países vecinos la instalación de las siete bases militares estadounidenses en el territorio latinoamericano.

\section{4. $A B C$}

Pertenece al grupo Vocento. Sede principal en Madrid. Posee un tiraje aproximado de 343.640 ejemplares diarios. En este diario el tema de Venezuela fue abordado en 20 oportunidades con el siguiente tratamiento periodístico:

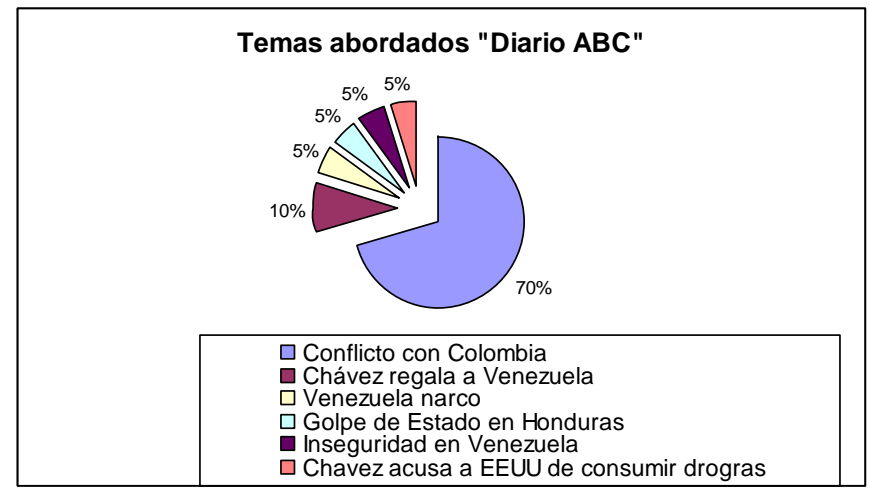

Gráfico No. 16. Temas abordados Diario ABC 
Año 1 (2010) | artículo ํㅡ 2 | Págs. 20 - 53

ISSN: 2172 - 3168

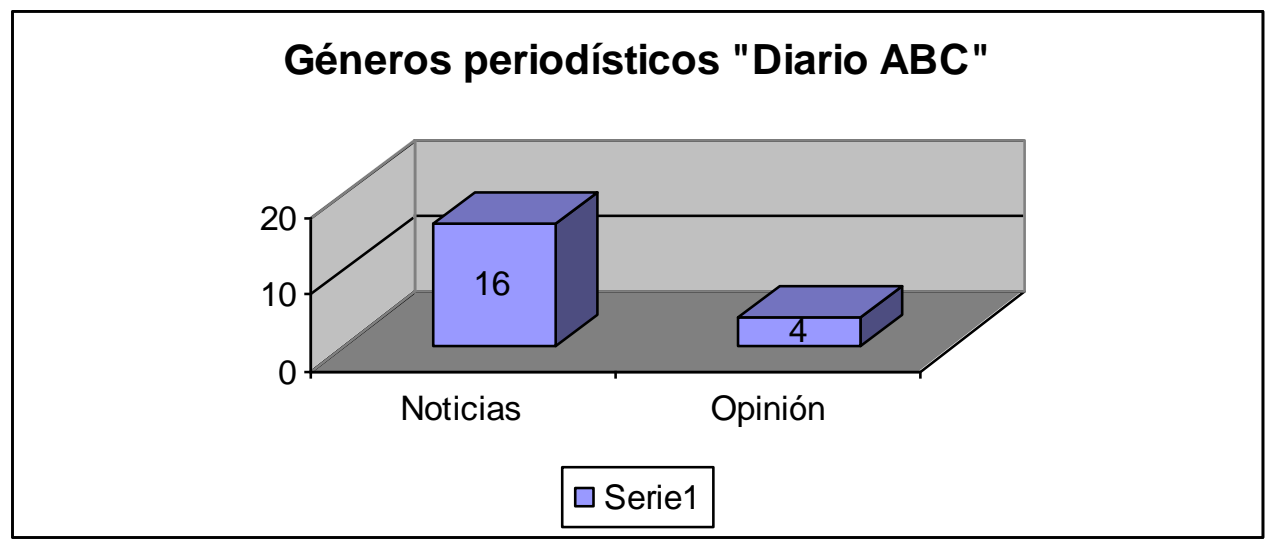

Gráfico No. 17. Temas abordados Diario ABC

Redactores "Diario ABC"

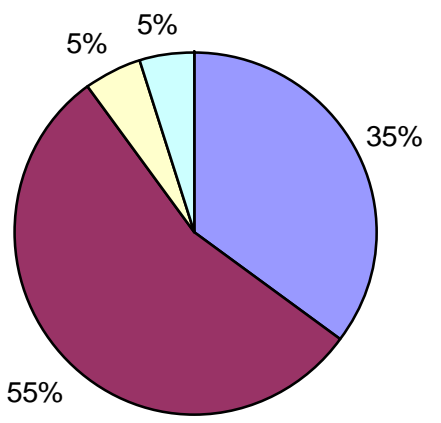

Agencias $\square$ Periodistas $\square$ Ex Ministro Méx. $1 \square$ No específico

Gráfico No. 18. Redactores Diario ABC 


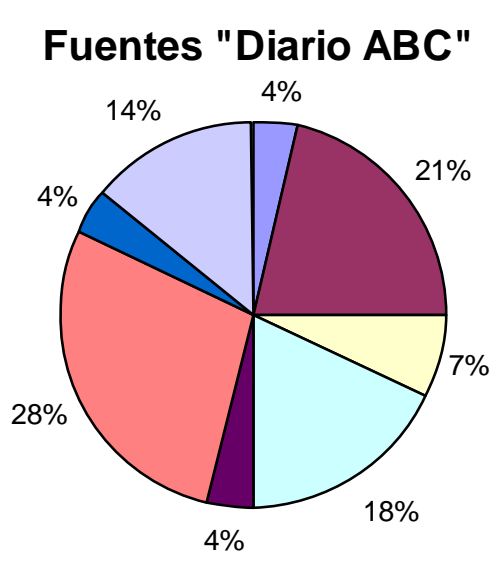

$\begin{array}{ll}\square \text { Personas de la comundidad } & \square \text { Chávez } \\ \square \text { Voceros aliados } & \square \text { Voceros enemigos } \\ \square \text { voceros neutrales } & \square \text { Sin voces } \\ \square \text { Voceros colombianos } & \square \text { Impresición de fuentes }\end{array}$

Gráfico No. 19. Redactores Diario ABC

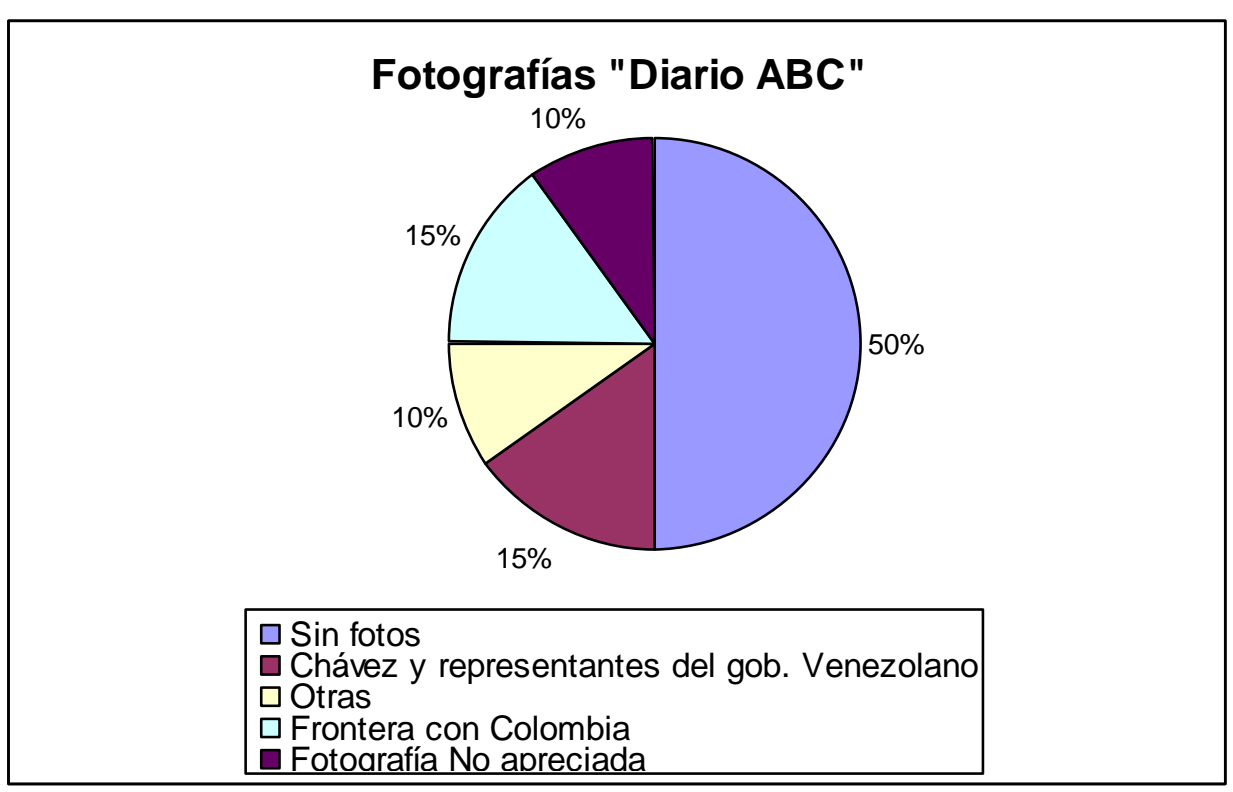

Gráfico No. 20. Redactores Diario ABC

1) El tema con mayor número de notas $(70 \%)$ fue el conflicto Colombia- Venezuela. Seguido de aquel donde se señala que el presidente Hugo Chávez regala a Venezuela (10\%) y por 
ello, la tiene en situación crítica. En el $20 \%$ restante se vinculó a Venezuela con el narcotráfico, el golpe de Estado de Honduras, la inseguridad entre otros.

Esto demuestra que todos los aspectos fueron abordados desde una perspectiva negativa.

2) Hubo predominio de la noticia como género periodísticos, las cuales fueron elaboradas en un $55 \%$ por periodistas y corresponsales, $35 \%$ procedían de las agencias.

3) Se precisó que el $28 \%$ de los trabajos publicados carecían de voces o fuentes. Otro 14\% mostraba imprecisión en el uso de la misma.

4) El Presidente venezolano fue empleado como fuente en el $21 \%$ de las notas. Se usaba la técnica de la repetición, es decir repetir las mismas palabras en notas distintas. Ejemplo:

a) "Hay que hablar con el amo y por eso le digo al presidente Barack Obama: no se vaya a equivocar y vaya a ordenar usted una agresión abierta contra Venezuela utilizando a Colombia" (Citado en 3 notas).

b) "Los venezolanos estamos dispuestos a todo" (Citado en 3 notas).

c) “¡Señores Uribe y Obama vayan a lavarse ese paltó!" (Citado en 2 notas)

d) "Nosotros estamos preparándonos para defendernos, no vamos a agredir a nadie" (Citado en 2 notas)

e) «Prepararse para la guerra». (Citado en 2 notas)

5) A nivel de títulos el Presidente Chávez es el agente activo (60\%) que ejecuta todas las acciones no sólo contra Colombia, sino contra Venezuela y los Estados Unidos.

\begin{tabular}{|c|c|c|}
\hline Títulos empleados & Fecha & Comentarios \\
\hline $\begin{array}{l}\text { Chávez insiste en prepararse ante la } \\
\text { «amenaza» de EEUU desde Colombia }\end{array}$ & $14-11-2009$ & \multirow{6}{*}{$\begin{array}{l}\text { Es Chávez quien ha } \\
\text { llevado a la quiebra a } \\
\text { Venezuela, ha triplicado } \\
\text { la violencia, amenaza a } \\
\text { Colombia, reparte los } \\
\text { recursos venezolanos a } \\
\text { fin de ganar adeptos en } \\
\text { otros países, manda, } \\
\text { pide, cierra grifos y } \\
\text { acusa. }\end{array}$} \\
\hline $\begin{array}{l}\text { Chávez ratifica su llamada a la guerra contra } \\
\text { Colombia }\end{array}$ & 14-11-2009 & \\
\hline Hugo Chávez reparte chuches & 12-11-2009 & \\
\hline $\begin{array}{l}\text { Chávez manda tanques a la frontera con } \\
\text { Colombia }\end{array}$ & $12-11-2009$ & \\
\hline $\begin{array}{l}\text { Los venezolanos no quieren ir a la guerra } \\
\text { como pide Chávez }\end{array}$ & $10-11-2009$ & \\
\hline Hora de enfrentarse a Chávez & 10-11-2009 & \\
\hline
\end{tabular}




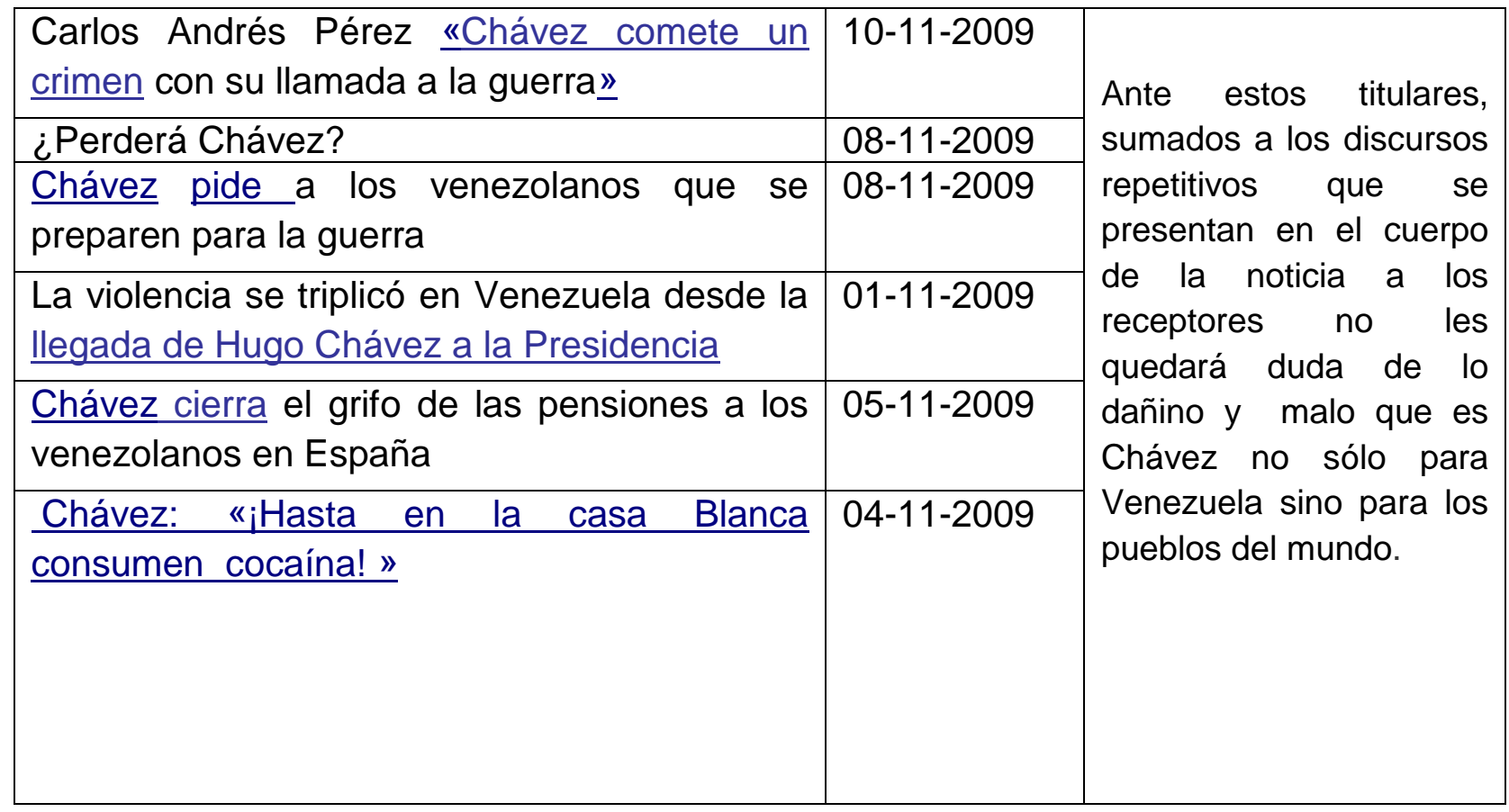

6) Se construye la imagen de una Colombia pacifista, que tiene como única intención implementar el acuerdo militar para efectuar operaciones contra el narcotráfico y la guerrilla.

\begin{tabular}{|l|c|}
\hline \multicolumn{1}{|c|}{ Títulos empleados } & Fecha \\
\hline Uribe llevará las amenazas de guerra de Chávez a la ONU & $10-11-2009$ \\
\hline $\begin{array}{l}\text { Colombia anuncia que llevará las «amenazas de guerra» de } \\
\text { Chávez a la ONU y la OEA }\end{array}$ & $09-11-2009$ \\
\hline $\begin{array}{l}\text { Colombia pide mediación de España en la frontera con } \\
\text { Venezuela }\end{array}$ & $07-11-2009$ \\
\hline Colombia y EE.UU. firman su polémico acuerdo militar & $30-10-2009$ \\
\hline
\end{tabular}

7) En el cuerpo de las noticias se refuerza la imagen de una Colombia que sólo tiene la intención de usar las bases militares para enfrentar el terrorismo y el narcotráfico existente en la zona. Ejemplo:

a) "Colombia no ha hecho ni hará ni un solo gesto de guerra a la comunidad internacional, y menos a países hermanos" (Citada en 3 notas, no se precisa quién es la fuente, sólo se habla de un comunicado). 
b) "El único interés que nos mueve es la superación del narcoterrorismo que durante tantos años ha maltratado a los colombianos", continúa el comunicado del Gobierno, que insiste en abogar en el conflicto con el país vecino por "las vías del entendimiento y de las normas del derecho internacional".

(Es decir, Colombia quiere paz, Venezuela es la conflictiva)

c) "Lo que se busca es contar con herramientas de cooperación técnica para ser más eficaces en las comunicaciones, en los mecanismos de inteligencia"

8) En ninguna de las notas publicadas se muestra a los receptores las repercusiones que pueden tener las bases norteamericanas para la soberanía de Latinoamérica. No obstante, las bases militares son mostradas como una estrategia de cooperación "positiva" para enfrentar las acciones de narcotráfico y terrorismo en Colombia.

Ejemplos:

a) "Bermúdez agregó que el interés de Colombia con este acuerdo es derrotar el crimen organizado $\mathrm{y}$, al mismo tiempo, tener las mejores relaciones con todos los países del continente.

b) "Lo que se busca es contar con herramientas de cooperación técnica para ser más eficaces en las comunicaciones, en los mecanismos de inteligencia" para la lucha contra el narcotráfico y las guerrillas izquierdistas, dijo el ministro.

\section{Conclusiones}

1) De las informaciones analizadas (82 publicaciones) la versión electrónica del diario El Mundo la que mayor cobertura le dio a Venezuela con un $34 \%$. El resto de los medios mostraron un comportamiento similar: El País (21\%), ABC (24\%) y La Vanguardia (21\%)

2) El tema con mayor incidencia en los 4 medios fue el conflicto Colombia-Venezuela (72\%), originado por la instalación de las siete bases estadounidenses en el territorio colombiano. El $12 \%$ estaba centrado en mostrar la imagen de una Venezuela con: corrupción, inseguridad, deterioro de la libertad de expresión, narcotráfico, drogas y que está en contra del golpe de Estado en Honduras. El tema del racionamiento de agua y luz que está llevando a cabo en Venezuela para enfrentar la crisis causada por el fenómeno del Niño y la falta de lluvias ocupó el $10 \%$. El resto (6\%) fue para hablar de la personalidad del presidente Chávez, la visita del presidente de Irán a Venezuela, y los señalamientos y acusaciones de Chávez hacia los EEUU. 
3) El $99 \%$ de las veces que se abordó el tema de las bases estadounidenses en el territorio colombiano se hizo con miras a exaltar la actitud "negativa", "hostil" y "agresiva" que Venezuela y el presidente Chávez ha tomado en relación al tema.

El diario El País fue el único medio que tocó, a través de un artículo de opinión, las repercusiones que pueden tener, para la soberanía de los pueblos latinoamericanos, la instalación de las siete bases norteamericanas en Colombia. Dicho artículo de opinión fue escrito por el ex - presidente colombiano, Ernesto Samper Pizano, en fecha 12-11-2009 y cuyo título fue: "Bases militares estadounidenses en Colombia"

Es fundamental mencionar que con la instalación de dichas bases los EEUU aseguran el control estratégico del hemisferio suramericano, con lo cual pueden vigilar, inmiscuirse y reorientar el destino de los pueblos latinoamericanos de acuerdo a sus intereses y necesidades.

4) Predominó la noticia como género periodístico (81\%). Seguido de los artículos de opinión $15 \%$. Sólo se publicó un editorial (diario el País) y éste con tendencia negativa sobre Venezuela y el Presidente Chávez.

Se observó que en las noticias los redactores emitían juicios de valor y cargaban de forma subjetiva su trabajo (propia de los géneros de opinión). Ejemplos:

a) "Chávez volvió a subir el tono en la crisis con Colombia". (El Mundo, 08-11-2009).

b) "Chávez no se puede mostrar más agresivo". (El Mundo, 09-11-2009 y la Vanguardia 09-11-2009).

c) "Añadió el presidente, en uno de sus arranques de emotividad". (ABC, 14-11-2009).

d) "Ante el alto voltaje que ha alcanzado en las últimas semanas el enfrentamiento entre Venezuela y Colombia" (EI País, 14-11-2009).

e) "En este conflicto que parece no tener fin" (El País, 14-11-2009).

f) En todo el continente americano sonó la alarma al escuchar cómo, en un tono amenazante, el presidente venezolano instó a civiles y militares de su país a "prepararse para la guerra" con su vecino" (La Vanguardia, 09-11-2009).

g) "Los políticos de la oposición e incluso los mismos chavistas no ven con buenos ojos eso de ir a la guerra contra Colombia o contra quien sea como lo ha pedido Hugo Chávez en su programa dominical "Aló Presidente", de quien últimamente se puede esperar cualquier cosa que le pase por su mente". (ABC, 10-11-2009) 
5) Los periódicos El Mundo y El País mostraron mayor uso de géneros periodísticos (noticias, entrevistas, crónicas, editorial, reseñas y artículos de opinión) para cubrir los hechos relacionados con Venezuela.

6) El personaje más citado es el Presidente Chávez (27\%). Hay que precisar que dichas citas fueron usadas con una estrategia repetida (negativa) para formar y anclar en el receptor la imagen de un Chávez belicista y agresivo. Ejemplos:

a) "No se vaya a equivocar y vaya a ordenar usted una agresión abierta contra Venezuela utilizando a Colombia" (citada en 9 notas).

b) "Prepararse para la guerra" (Citada en 6 notas).

c) "Tres minutos son suficientes... iy no quedo hediondo!", ha dicho de sus propios baños. O llama al ahorro de electricidad, y amenaza con expropiar los centros comerciales que no reduzcan su consumo de energía, una energía que pertenece al "pueblo". (Citada en 6 notas)

d) "El gobierno de Colombia no está en Bogotá, ahora está en Estados Unidos" (citada en 4 notas)

e) ¡Señores Uribe y Obama vayan a lavarse ese paltó!" (Citado en 3 notas)

f) "Los venezolanos estamos dispuestos a todo" (Citado en 3 notas).

g) "Son las bases militares yanquis" (citada en 2 notas)

h) "Compañeros militares, no perdamos un día en el cumplimiento de nuestra principal misión: prepararnos para la guerra y ayudar al pueblo a prepararse para la guerra, porque es una responsabilidad de todos. (...) No pierdan tiempo, vamos a formar los cuerpos de milicias, los estudiantes, los trabajadores, las mujeres, todos listos para defender esta patria sagrada que se llama Venezuela, patria santa", ha añadido, extendiendo también el llamamiento a comandantes de batallones y milicias, a estudiantes revolucionarios, trabajadores y mujeres. "Todos listos para defender esta patria sagrada" (citada en 2 notas)

7) Se construye la imagen de víctima de Colombia y del presidente Uribe. Es decir, Colombia no tiene otro objetivo que usar las bases con la finalidad de desarrollar acciones contra el narcotráfico y el terrorismo. Ejemplo:

a) "El único interés que nos mueve es la superación del narcoterrorismo que durante tantos años ha maltratado a los colombianos" (citada en 3 notas). 
b) "Colombia no ha hecho ni hará un solo gesto de guerra a la comunidad internacional, menos a países hermanos". (citada en 3 notas)

8) El $46 \%$ de los trabajos publicados fueron elaborados por periodistas corresponsales. Las agencias de noticia tienen un papel fundamental en la construcción de la imagen de Venezuela dado que de ellas provienen el 39\% de la información publicada.

El Diario El Mundo fue el medio con mayor publicación de notas procedentes de agencias (60\% de sus trabajos).

9) El $52 \%$ de las publicaciones no tenían fotografías. De las notas con fotografía el $13 \%$ fue para representar gráficamente la situación de la frontera colombo-venezolana. La imagen de Chávez fue mostrada en un $12 \%$.

10) En términos generales, el $94 \%$ de los temas abordados por los medios electrónicos, tienden a mostrar una imagen negativa de Venezuela y el Presidente Hugo Chávez. La República Bolivariana de Venezuela se asocia con: crisis, corrupción, narcotráfico, terrorismo, asesinatos, secuestros, drogas, escasez de agua, luz y próximo a participar en una guerra. Por su parte, Chávez es desdibujado como un personaje agresivo, eufórico, desequilibrado, dispuesto a todo para satisfacer sus necesidades individuales y permanecer en el poder.

\section{Bibliografía}

- KRIPPENDORFF, Klaus (1990). Metodología de análisis de contenido. Edit. Paidós. Barcelona.

- M`BOW, Amadou Mahtar. (1989). Información y Comunicación en el mundo contemporáneo. (Lección inaugural de la Facultad de Ciencias de la Información de Sevilla, curso 1989-1990). Cuadernos de comunicación, Fac. de CC de la Información. Universidad de Sevilla. Editor Asociado, Ediciones Alfar, Sevilla. España.

- OFICINA ECONÓMICA Y COMERCIAL DE ESPAÑA EN CARACAS (2009). "Venezuela. Informe Económico y comercial 2009". [En línea] Disponible en: http://www.icex.es/icex/cma/contentTypes/common/records/viewDocument/0,,,00.bin? doc $=4252781$ [Consulta: 2010 , febrero 10]. 


\section{Forma de citar este artículo en bibliografía}

Marianela Urdaneta García (2010): "La imagen de Venezuela y Chávez en la prensa electrónica española”, en Revista PANGEA, 1, páginas 20 a 53. Red Académica Iberoamericana de Comunicación. Recuperado el _ de ___ de 2 __ de: http://revistapangea.org/2010/09/13/01-01-102/ 